\title{
Revisiting the mining controversy of Bangka Island, Minahasa Regency, North Sulawesi, Indonesia
}

\author{
Flora Pricilla Kalalo \\ Faculty of Law - Sam Ratulangi Unviversity, Manado, Indonesia
}

\begin{abstract}
Bangka Island in North Sulawesi is home to several endemic and endangered terrestrial and marine wildlife and at the same time a well-known tourist destination is facing a serious threat to irreversible environmental destruction due to mining activities. Although finally ordered closure by Indonesian Supreme Court, the initial mining activities have greatly impacted the highly critical environment of Bangka Island. The authors examined the documents (including government-issued permits as well as related laws and regulations) and interviewed key respondents as to their knowledge of the supposed mining activity and their perceived impacts. Results revealed that there were lapses in the Indonesian government's side in issuing permits. The respondents $(\mathrm{N}=35)$ are fully aware of the said mining activity and its potential impact on the livelihoods (mainly fishing and tourism) that highly depend the to the fragile island ecosystem of Bangka Island.
\end{abstract}

Keywords: Bangka Island, environment, mining, North Sulawesi, permits, tourism, zoning.

\section{Introduction}

Bangka Island in Minahasa Regency, North Sulawesi, Indonesia is well-known because of its marine and terrestrial biodiversity [1]. Despite a small area with only 7,778 hectares, it is home to several endemic mammals such as the Javanese deer (Rusa timorensis), tarsier (Carlito syrichta), common cuscus (Phalanger orientalis), Asian water monitor lizard (Varanus salvator) and wild boar (Sus scrofa). Extensive coral reefs also host a wide array of tropical fish species, such as Napoleon Wrasse (Cheilinus undulatus), frogfish (Antennarius spp), pygmy seahorses and nudibranchs, as well as Dugong (Dugong dugon): a marine mammal considered under Vulnerable status by the International Union for the Conservation of Nature. Bangka Island is located close to Bunaken Marine National Park, a popular marine-based international tourism destination. However, Bangka does not have protected marine park status. One of the threats to the coral reefs of Bangka Island is the potential negative effects from mining activities [2].

In 2008, the Regent of North Minahasa, Sompie Singal, issued a permit to PT Mikgro Metal Perdana (PT MMP), a subsidiary of the Hong Kong-based Aempire Resource Group, to explore for iron ore on Bangka, with subsequent extensions (twice) on 20 July 2010, and 20 July 2012. The concession area covers 2,000 hectares and the 2012 extension was broadened to cover "iron ore and other minerals". Many Bangka residents and the local tourism operators opposed the mining plan, out of fear that a full-scale mining operation and pollution would devastate Bangka's fragile ecosystem and subsequently destroy traditional livelihoods and eco-tourism. Residents and the tourism operators sued the Regent and PT MMP hoping to prevent the mining from full operation. Part of the bases of the said lawsuit is the fact that Bangka is a small island as stipulated by Law No.27/2007 on the Management of Coastal Areas and Small Islands. According to this law, mining is considered illegal on islands smaller 
than $2,000 \mathrm{~km}^{2}$. Bangka has a surface area of just about $48 \mathrm{~km}^{2}$, a stark contrast to what is allowed by the law.

Despite opposition from stakeholders, PT MMP and local government officials pressed ahead with the mining plan, insisting it will bring economic benefits. Clearly, the mining activities on the island, polarized the residents of Bangka Island. In fact, both sides resorted to accusations. For example, the Director of PT MMP, Yang Yongjian, accused a nongovernment organization of masterminding anti-mining protests in an effort to extort money from his company, without mining the NGO.

The main purpose of this paper was to understand in a more comprehensive manner the mining controversy. We investigate further into Bangka Island's history and emphasize the factors in terms of why and how mining operators obtained permit(s) to mine the island. In other words, was there failure in implementing pre-mining screening?

\section{Methodology}

\subsection{The study area}

The study was conducted in Bangka Island, North Sulawesi, Indonesia (Figure 1). It has a total land area of 4,778 hectares. It belongs administratively to the district of East Likupang in the North Minahasa regency, North Sulawesi province. The island has three main coastal villages: Lihunu, Kahuku and Libas. As of the census in 2010, the island's total population was only 2,397 inhabitants (Lihunu 1,029, Kahuku 938 and Libas 430). Bangka is located southwest of Biaro Island, being separated only by the Bangka Passage. West of Bangka are the following islands: Kinabohutan, Talisei, Tindila and Gangga. Geographical features of the Bangka are forests, hills, coconut plantations, rocky outcrops, mangroves and pristine beaches.

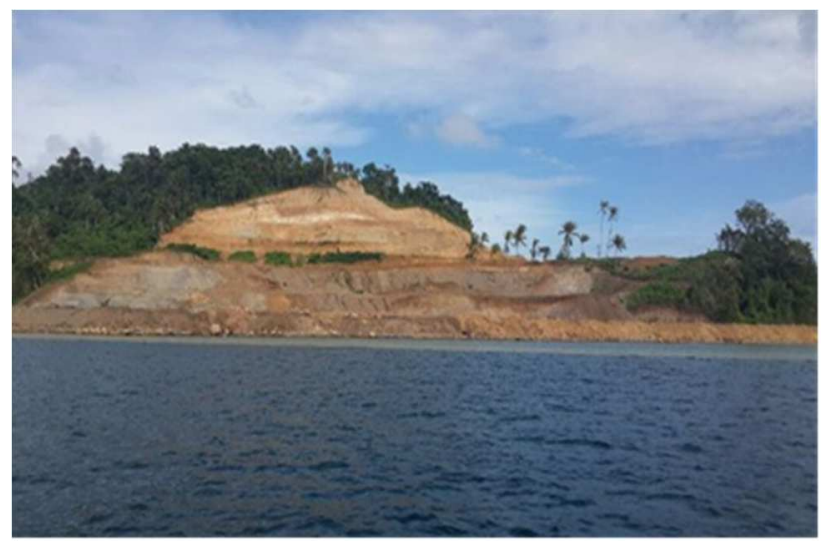

Fig. 1. Map showing the location of Bangka Island, North Sulawesi, Indonesia.

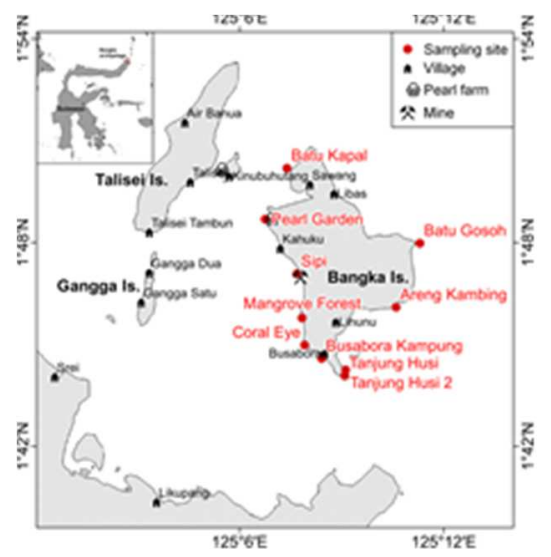




\subsection{Data Gethering}

With the aid of trained interviewers, direct and indirect interviews with key persons (former and current officials), reliable residents were conducted between April 10-28, 2018. During interviews, field assistants assure the respondents that names of interviewed persons will not be mentioned in any report as part of the confidentiality agreement and also not to intimidate the subject due to the sensitivity of the topic. The respondent's profile is presented in Table 1 and the data sheet with key questions (served as cues) to guide the interview is attach as Appendix A. In general, we followed the approach used by other investigators [3][4].

We also reviewed published literature (journals, reports, etc) and examined relevant laws and related documents accessible as public documents like permits given to the mining company, etc.

\section{Results and Discussion}

\subsection{Respondents profile and environmental awareness}

The age of the 35 respondents ranged from 16-72 years old (modally 19). Majority 19 (54.29\%) of which are fishermen (with at least 5-10 years in fishing). The rest of the occupation included civil servants, traders, and junior and senior high school students. It is of interest to note that majority of the respondents are fully aware of the ecosystems present on the island as well as the benefits derived from such ecosystems and also able to suggest potential impacts of human activities such as illegal fishing, pollution (solid wastes such as plastics), and mining.

Table 1. Summary profile of the respondents who participated during interviews $(\mathrm{N}=35)$.

\begin{tabular}{lll}
\hline Participants & $\begin{array}{l}\text { Number } \\
(\mathrm{N}=35)\end{array}$ & $\%$ \\
\hline Age: & $16-72(19)$ & \\
Education: & & \\
High School & 20 & 57.1 \\
Elementary & 13 & 37.1 \\
College & 1 & 2.9 \\
Occupation: & & \\
fisher & & \\
civil servant & 19 & 54.3 \\
housewife & 5 & 14.3 \\
retired & 3 & 8.6 \\
student & 1 & 2.9 \\
trader & 3 & 8.6 \\
\hline
\end{tabular}




\subsection{Respondents knowledge on environmental degradation and mining}

The respondents were also aware as to the name of the mining company involved with the present controversy and $18(51.43 \%)$ are also aware the mineral being mined (iron ore) and even identified this material has been shipped to China.

Majority of the respondents identified the owner of the mining company as MMP (Micgro Metal Pedrana, a subsidiary of the Hong Kong based Aempire Resource Group under Shenzen Energy from Guandong/China) that started operating in 2012. However, 15 (42.86\%) said the company never consulted the local inhabitants prior to the mining activities while 20 $(57.14 \%)$ said otherwise, insisting that the locals were consulted about the project. Almost all of the respondents also claimed that there were violations as to environmental laws committed both by the Indonesian government (e.g. issuing permits) and the mining company. For example, the island, which has a total land area of less than $2,000 \mathrm{~km}^{2}$, should be included as tourism zone based on the Government Regulation No.26/2008.

Generally, the locals do not have the trust on the mining company due to restricted access to the area and intimidation such as the presence of armed security personnel. Such intimidation may have also forced some of the locals to sell their land. Mistrusts between the local inhabitants and the mining company further developed as a result of legal battles fought since 2012. A brief account on the development of court cases is provided below: (a) Manado Administrative Court (in Decision No.04/G.TUN/2012/PTUN.MDO) on 30 August 2012, rejected a lawsuit by Bangka residents and tourism operators to cancel the exploration permit; (b) the mining operators successfully appealed at the High Administrative Court of Makassar, South Sulawesi, which on 1 March 2013 (in Decision No.165/B.TUN/2012/PT.TUN.MKS) overturned the Manado Court's ruling, wherein the judges accepted all points of the plaintiffs' case, the verdict revoked the exploration permits and their extensions; (c) the Regent and PT MMP rejected this verdict and appealed to the Supreme Court in Jakarta, which later on (23 September 2013); (d) their appeal was dismissed by the Supreme Court. Despite having lost several times at different judiciary levels, the mining company still control the mine site. More recently, for example, a ship that was boarded by a number of journalists and NGO Network Advokasi Tambang (Jatam) who joined with the entourage to the island of Bangka on Thursday (26/04/2018) at the mine site at PT Mikgro Metal Perdana (PT MMP) was stoned by pro-mine citizens.

It can be recalled that in Government Regulation No.26/2008 or the National Spatial Planning and Government Regulation No.50/2011 on National Tourism Development Planning, Bunaken National Park and its "surrounding areas" should be regarded as a strategic area for marine tourism, conservation and fishing. In addition, almost the entire concession area of 2,000 hectares granted to PT MMP belongs to the Limited Production Forest Zone. In such a case, a special permit must be properly obtained from the Forestry Ministry, through the North Sulawesi Governor, prior to exploration activities. Apparently, this was not followed, thus in effect, making PT MMP's exploration permit a violation of Law No.41/1999 on Forestry.

\subsection{Respondents and the mining application process}

As described by Rosyida et al. [5], issuing licenses for mineral extraction in Indonesia is authorized by state regulations and policies pertaining to sea mining activities, including Decree No. 4 of 2009 (Minerals and Coal), Decree No. 27 of 2007 (Management of Small Islands and Coastal Resources), and Decree No. 32 of 2009 (Protection and Management of 
the Environment). Based on these regulations, all mining companies are required to conduct environmental feasibility studies and environmental impact assessments (EIAs), on top of paying royalties. Because of a shift from a centralized to a decentralized government encouraged district-level governments to draft their own rules governing natural resources, giving district heads the authority to issue permits for mining operations. Nevertheless, full legal compliance with state environmental regulations has thus become an increasingly insufficient means of satisfying society's expectations with regard to mining issues. Furthermore, a report published by Guardian in 2015 stated that the Environmental Impact Assessment (EIA) was approved by 26 out of 27 government officials and specialists, despite the global significance of Bangka's coastal ecosystems and its close proximity to the Bunaken National Park, home to some of the highest levels of marine biodiversity on earth. In fact, only one specialist (Veronica Kumurur, Head of Urban and Regional Planning at Sam Ratulangi University in Manado did not vote in favour of the EIA. V. Kumurur explained that since the company didn't submit a detailed engineering plan, then they cannot assess the environmental impact. She also quoted the company's intention to build a dam and a smelter on the island, which is possible without damaging Bangka's unique ecosystems.

J. Langenheim [6] published a short article in 2015 about this legal morass, which according to him common in Indonesia, with local officials issuing controversial permits to extract natural resources, sometimes in violation of national laws. Corruption within the judicial system can make it all the more difficult to challenge controversial resource extraction contracts. In addition, as of March 2015 alone, local administrators in North Sulawesi had issued a total of 145 mining licenses (IUP) based on the information provided by the General Mining Sector of the Department of Energy and Mineral Resources in North Sulawesi. Although in a subsequent interview, this was denied by no less than the governor of North Sulawesi during that period.

\subsection{Concluding remarks}

The animosity between anti-mining groups and pro-mining groups, including some residents, developed over time. In fact, an anti-mining group who tried to dock at the mine site on April 27, 2018 was greeted with stones. This happened a few days since the announcement of the Department of Energy and Mineral Resources on the mining company's permit. There is also reason to believe that some of the stakeholders (e.g. those associated with the diving industry, NGO workers, etc) are using the situation to further their group's own interest and never thought of the holistic progress that might be brought about by mining. In fact, conflicts between NGOs, companies and government has been there since the late 1990s including the wide use of internet [7]. On the other hand, mining has been documented to have negative impacts on the marine environment, especially in coral reefs of Indonesia [8]. In other words, it is the responsibility of the government to impose certain laws in a non-partisan way so that conflicts between a mining company and other stakeholders, including dive operators could been avoided or minimized. Laws mentioned above such as mining and zoning regulations are already in place, it is only a matter of impartial implementation, including strict screening of mining applications, on the part of the government. 


\section{Recommendations}

Apparently, enhancing governance especially in implementing measures on the part of the Indonesian government and continued vigilance, monitoring, a role which can be done by concerned citizens and stakeholders (fishers and diving operators) should be considered an ultimate goal. Future researchers are also encouraged to tackle this issue carefully so that the experience in Bangka Island will not be repeated in other biodiversity-rich areas in Indonesia (and even in other developing countries). As to who should have legal liabilities, whether or not there was indeed corruption at various levels of the government's offices, is up to the Corruption Eradication Commission (KPK). It has always been said that "prevention is better than cure" that we recommend strict and stringent application process for mining operations but this can only be done if corruption has been completely abolished, otherwise, the same problem(s) are to be expected. If indeed violations were made by the mining company, we recommend that a thorough scientific assessment be made as to whether or not the company needs to pay for the environmental damages inflicted by the mining operation.

\section{Acknowledgment}

We wish to acknowledge the following individuals and organizations who greatly helped us by providing relevant information used in this study: Merryani Bawole and "Masyarakat Desa" Kahuku, Libas in Bangka island. We also thank the following students who helped us during the conduct of the interviews.

\section{References}

[1] Hakim, L., Soemarno, M., \& Hong, S. K.: Challenges for conserving biodiversity and developing sustainable island tourism in North Sulawesi Province, Indonesia. Journal of Ecology and Environment. Vol. 35(2). pp. 61-71 (2012)

[2] Ponti, M., Fratangeli, F., Dondi, N., Reinach, M.S., Serra, C., \& Sweet, M.J.: Baseline reef health surveys at Bangka Island (North Sulawesi, Indonesia) reveal new threats. PeerJ. 4, e2614 (2016)

[3] Kalalo, F.P.: Law enforcement and conservation at Bunaken National Park, North Sulawesi, Indonesia as perceived by the local coastal communities. AACL Bioflux. Vol. 10(6) (2017)

[4] Chassels, M. R., \& Bucol, A.A.: "Participatory conservation in the Philippines: The case of Luyang Mangrove Reserve in Siquijor, Central Philippines. Silliman Journal. Vol. 52(1). pp. 144 $155(2011)$

[5] Rosyida, Isma., \& Wahidullah Khan, M. S.: Marginalization of a coastal resource-dependent community: A study on Tin Mining in Indonesia. The Extractive Industries and Society. Vol. 5(1). pp. 165-176 (2018)

[6] Langenheim, J.: Controversial mine threatens Indonesian dive mecca. The Guargian (2015)

[7] Bray, J.: Web Wars: NGOs, Companies and Governments in an Internet-Connected World. Greener Management International. Vol. 24 (1998)

[8] Brown, B.E., \& Dunne, R.P.: The environmental impact of coral mining on coral reefs in the Maldives. Environmental Conservation. Vol. 15(2). pp. 159-165 (1988) 